\title{
Job Creation, Poverty Reduction and Conflict Resolution in North Eastern Nigeria
}

\author{
Lawan Cheri \\ Department of General Studies, Federal Polytechnic Damaturu
}

\begin{abstract}
The North Eastern region of Nigeria is fast becoming a theater of skirmishes and full-blown war between government forces that wish to keep the country as one, indivisible and secular nation and those who wish to transform it into a theocratic state. Another strong opinion has it that the crisis was hijacked by political warlords that are perpetuating the conflict for political reasons. Whichever theoretical assumption is alleged, it cannot be disputed that the crises is sustained by the ever increasing army of jobless youth that are ready to be engaged for whatever purpose as long as it can fetch a means of livelihood. The paper assumes that one of the basic functions of government is to provide a favorable economic environment for citizens to thrive and contribute meaningfully to the development of the nation. This paper is an attempt to assess the relationship between job creation, poverty reduction and conflict resolution. The paper uses documentary analysis to examine how job creation in North Eastern Nigeria can reduce poverty in the area and reduce the possibility of escalating violence.It recommends among others, that governments at all levels should prioritize job creation and poverty alleviation programs in the region through government and non-governmental agencies. It also recommends strengthening the private sector to complement the efforts of government in employment generation.
\end{abstract}

Key Words: Job, Poverty, conflict, conflict-resolution

\section{Historical Background of Poverty and Conflict in North Eastern Nigeria}

President Olushegun Obasanjo titled his 2005 budget as "Building Physical and Human Infrastructure for Job Creation and Poverty Eradication." This apt title given to an annual budget of a country that suffers from unemployment and povertycreates expectations that the economy will be reformed and youth will be productively engaged thereby reducing idleness and the propensity of engaging in violent activities as well as improvement of security of life and property of Nigerians. Subsequent budgets were also planned towards same direction but both poverty, and unemployment continue to increase in the country leading to general dissatisfaction, apathy, and rising social uprisings aimed at not only changing the leaders but the system. This becomes more disturbing in the North eastern region where the emergence of Boko Haram crises in 2009 killed thousands of people, crippled the already suffering economy and plunged the region into a state of anarchy amidst the presence of heavy security personnel and equipment. This social rebellion rises injuxtapositionwith theescalation of poverty and unemployment where in 2004 the region was the worst hit by poverty and in 2010 became just 1.4 point better than the North West region of the country.

This necessitates academic research to ascertain the level of influence that unemployment and poverty are having on the skyrocketing violence that seems to bedevil the North Eastern society and the country at large and try to point out how job creation and can lead to poverty alleviation and reduce the tendency of youth to engage in violent activities.

\section{The Concept of Poverty}

Like all other social science concepts, poverty defies a universally acceptable definition. The term is defined by several authors and organisation's but almost all are united in calling it a condition or situation where a person lacks the necessary requirements of a decent life.

According to the United Nations, "It means lack of basic capacity to participate effectively in society. It means not having enough to feed and clothe a family, not having a school or clinic to go to; not having the land on which to grow one's food or a job to earn one's living, not having access to credit." While the World Bank explains poverty to "includes low incomes and the inability to acquire the basic goods and services necessary for survival with dignity. Poverty also encompasses low levels of health and education, poor access to clean water and sanitation, inadequate physical security, lack of voice, and insufficient capacity and opportunity to better one's life" (Olanrewaju, 2011). Deprivation and lack forms the fulcrum around which the two definitions revolve.They are both united in associating poverty with lack of access to education and health both of which makes a person unemployable, and socially unfitting of being a member of a formal organization. 
These definitions depicts a good picture of most Nigerian societies where citizens who live below the poverty line are increasing by the day and almost all human development indices are pointing to low standard of living, penury and general discomfort. According to the National Bureau ofStatistics (NBS), "shortly after independence in 1960 about 15 per cent of the population was poor. This rose to 28 per cent in 1980. By 1985, it had risen to 46 per cent, dropping to 43 per cent in 1992 . However, by 1996 the poverty incidence had gone up to 66 per cent before climbing further to $93.9 \%$ per cent in 2010" (NBS, 2010; Olanrewaju, 2011).

In most of these indices, the North Eastern region of the country appears the worst hit by the poverty trap. Its income inequality level is the worst with 0.4468 , and with $76.3 \%$ of itspopulation living in poverty, it is only second to the North West region with $77.7 \%$ (NBS, 2012).

Table 1.1: Trends in level of Poverty by Zones $(1980$ - 2010)

\begin{tabular}{|l|l|l|l|l|l|l|}
\hline ZONE & 1980 & 1985 & 1992 & 1996 & 2004 & 2010 \\
\hline South South & 13.2 & 45.7 & 40.8 & 58.2 & 35.1 & 63.8 \\
\hline South East & 12.9 & 30.4 & 41.0 & 53.5 & 26.7 & 67.0 \\
\hline South West & 13.4 & 38.6 & 43.1 & 60.9 & 43.0 & 59.1 \\
\hline North Central & 32.2 & 50.8 & 46.0 & 64.7 & 67.0 & 67.5 \\
\hline North East & 35.6 & 54.9 & 54.0 & 70.1 & 72.2 & 76.3 \\
\hline North West & 37.7 & 52.1 & 36.5 & 77.2 & 71.1 & 77.7 \\
\hline
\end{tabular}

Source: CBN cited in Yobe Economic Submit, 2008; NBS HNLSS report, 2012

Going by table 1.1, trend of poverty across geopolitical zones indicates that in all the six surveys carried out, the North West and North East regions are the most poverty stricken. This explains the frequent number of ethno-religious and political violence going on in the two regions dating back to theMaitatsine crisis of early 80s, the political riots of 2003-2011 and the present Boko Haram crises.

\section{Relationship between poverty and Conflict}

The relationship between poverty and violence is an item of academic polemics for a long time. Is poverty a cause of violence or vice versa? Are they mutually reinforcing or independent of each other? This paper asserts that they have an egg and chicken relationship where one leads to the other and strengthen it. Most civil wars were fought in economically less developed nations like Somalia, Rwanda, Myanmar, Syria, Haiti and Nigeria while economically developed and richer countries hardly experience civil wars. However, this is not asserting that richer nations do not experience poverty related violence. A study carried out in Chicago on Neighborhood and violent crime found out that even in richer societies, resource deprivation (poverty) or what the authors called "concentrated disadvantage" increases the propensity of violence (Sampson, Raudenbush, and Earls, 1997). This reveals that when poverty increases in both intensity and extensity, poor people are forced to feel a sense of alienation, deprivation and exploitation which may ignite love for revenge against the source of deprivation.

Nonetheless, this is more pronounced in situations of extreme income inequality. Whenever people become aware that few individuals own most of the resource while most of the people wallow in absolute penury, it usually ignites a blame game which has always been the case in Nigeria. In its report titled "Breaking the Conflict Trap" The World Bank opined that widespread income inequality increases the chance of violence by worsening social distrust, and "increases the perception of relative deprivation" which may result in "perceived grievances and potential strife." This explanation is exemplified in Nigeria where few individuals are getting richer and the poor are getting poorer by the day. It is unfortunate that the number of Nigerians living below the poverty line keep increasing even under the widely welcomed democratic dispensation. This explains why the report specifically states that "fragile democracies that provide universal suffrage, but do not have the institutional capacity to manage social stress, are clearly vulnerable to collapse" and concludes that "the key root cause of conflict is the failure of economic development." Nigeria's failure to achieve economic development especially in the North eastern part of the country where there is virtually no presence of any nationally recognized company of whatever type is a pity and a pointer to woeful economic failure. This situation leaves millions of youth unemployed and willing to partake in violent activities partly as a means of earning a living and partly as the only weapon of revenge against both perceived and real oppressors.

Hence, political and religious extremist are therefore utilizing the deep and widespread poverty in the region to recruit foot soldiers into their violent groups. Political extremism, religious intolerance, clash of civilizations, cultural globalisation and many other factors are blamed for frequent conflicts across the world but a fact that cannot be divorced away from all conflicts is that poverty ensures steady supply of ground troops that do the dirty job. While explaining the causes of violent attack on USA on September 2001, the then President of the country George W. Bush remarked:

The events of September 11, 2001, taught us that weak states, like Afghanistan, can pose as great a danger to our national interests as strong states. Poverty does not make poor people into terrorists and 
murderers. Yet poverty, weak institutions, and corruption can make weak states vulnerable to terrorist networks and drug cartels within their borders.

With 92 percent of Nigerians living below the poverty line (Olarenwaju, 2011), and weak law enforcement institutions that cannot ensure security of live and property, coupled with poor ratings of Nigeria in its fight against corruption by prominent anti-corruption bodies like Transparency International, Nigeria fulfills all the three preconditions of conflict as explained by Bush. Specifically worst, is the North Eastern region that has the highest mortality rate among the six geopolitical zones, has the highest rate in the country of male respondents who reported having no educational attainment whatsoever, and the second highest rates of female respondents reporting they had no educational attainment. Bauchi is the fourth $(84 \%)$ and Yobe is the fifth $(81.75 \%)$ statein the country with the highest rates of absolute poverty. (AOAV \& NWGAV, 2013).

\section{Violence in North Eastern Nigeria}

Violence can be defined as the use of unjustified force to injure somebody or damage something or the intimidating effects it creates. Violence is therefore any misconduct that is intended to hurt another person. It can be categorized into ethno-religious violence, mindless violence, political violence, economic violence or domestic violence, but whichever form it takes, violence is most often perpetrated by unemployed or underemployed youth. Poverty stricken youth are easily influenced by ethnic warlords, religious extremists or unscrupulous politicians to perpetrate violence against others.

Though, in recent years conflicts in North Eastern part of the country is primarily caused by the Boko Haram Insurgency, previous records indicate that there were serious indications of armed violence in the state prior to the emergence of Boko Haram. Dating back to the military era, Borno and Yobe states in particular were the hub of armed robbery in the country and with the emergence of bitterly competitive politics in the fourth republic; politicians started politicizing the armed robbers for political ends resulting in increased armed crime in the region.

Borno is the most conflict-affected state in the country. Since independence, the government has changed 14 times, on seven occasions through bloody military coups. The Nigeria Security Tracker recorded more than 8,600 deaths nationwide between May 2011 and August 2013 because of political, economic and social violence; 2,470 (28.7\%) were in Borno.The state also had the highest recorded levels of political violence in the Armed Conflict Location and Event Dataset, at 473 separate conflict incidents since 1997.(AOAV \& NWGAV, 2013).

This shows that the Boko Haram crisis is an outcome of a cumulative effect of poverty, unemployment and series of minor violent events that predates its emergence. Hence, addressing the crises requires special attention on its major causes including unemployment and poverty.

\section{The relationship between job creation and conflict resolution}

This section must start with a clarification that youth unemployment is usually not a direct cause of violence and conflict but it only proliferate it by supplying able bodied personnel that are ready to be engaged. As such, employment generation will not stop violent crimes at once, but it will cut the supply lines which will eventually make the violence unattractive, unsustainable and unworthy.

There are growing evidences that coupled with lack of job, political ethic and other grievaces arising from marginalization and denial of opportunities fuels armed conflicts. Most contemporary conflicts are caused by a general feeling that the political system is unjust and is responsible for state failure. Then unemployed youth take center stage and unleash violence feeling that they stand to lose nothing in case of failure and stand to gain everything in the event of success. Therefore job creation must go side by side with negotiations, compensations, and awareness creation. Walton, (2010) observed that "While many early recruits to rebel groups such as the RUF in Sierra Leone or the JVP in Sri Lanka were unemployed, for example, the motivating factor behind violence was not unemployment per se, but rather grievance at an unjust and corrupt patrimonial system that increasingly shut out young people."

Thus, the assumption that unemployment and poverty are directly linked to armed conflict remains strong in scholarly researches, and therefore an attempt to reduce unemployment and boost growth will help to prevent or reduce violence. 'Greed' or opportunity perspectives typically see armed violence as the outcome of rational individual choices to maximize economic, social or political benefits. Insurgence can only be attractive if the prospects of gain outweigh the benefits of not fighting and pursuing alternative income-generation opportunities (Urdal, 2007). From this perspective, the costs of organizing rebellion are lower where there is a large unemployed youth population, where there are high levels of poverty or where there is an abundance of easily lootable resources (Collier and Hoeffler 2004). This perspective is in tandem with the views that armed conflict can be effectively handled through job creation initiatives in societies with large, unemployed youth. By providing alternative sources of income in a peaceful environment, the probability of tilting individual choices away from conflict will be high. 
However, care must be taken to plan for a population that contains both unemployed and underemployed youths because most youth device a means of earning a living though they can neither sustain the business nor can the business sustain them at the long run. Most poverty alleviation and job creation programmes plans for fully unemployed youth and this tends to create more problems for the success of the programmes because the beneficiaries may not give enough time $t$ learn the skills or assume responsibilities. Not only that, job creation must target reduction in inequality because even if the whole population is engaged, there will be grievances if very few are earning enough to keep a family and the majority are underemployed. This questions SURE-P's method of engaging street sweepers and paying them 10,000 per month which is less than the national minimum wage and certainly not enough to maintain a family. This will only increase social bond and mutual sympathy among a group of socially disgruntled people which may serve as a nexus for future violence.

This tricky situation makes it difficult to understand why youth engage in armed violence since some of those engaged may not be poor and there are many poverty stricken youth that refused to be enticed to join armed groups. It is even more difficult to precisely earmark the role played by job creation in reducing unemployment and poverty and how reduction in the two aspects can forestall further conflict. Walton, (2010) identify four perspectives and their various assumptions on the issue as well as how job creation can play a role in settling disputes caused by such factors.

The perspectives identified include Greed/Opportunity viewpoint that beliefs that conflict is an outcome of a person's decision after being convinced that he/she can increase his/her economic or political benefit through violence. They believe that Man's insatiable need and the limited nature of resources makes competition necessary. This competition in turn can come in different forms healthy or unhealthy, peaceful or violent. This perspective believes that the choice to engage in peaceful or violent form is squarely an individual choice and therefore underplays the influence of external factors.

Grievance perspective sees armed violence as a response to relative deprivation or exclusion. This perspective tends to be more concerned with the societal or group dynamics of violence. This perspective justifies job creation schemes on the grounds that they can reduce inter-group grievance. Group employment schemes such as public works initiatives may also help to build solidarity amongst beneficiaries. The grievance lens appears to support more targeted youth job creation interventions, based on a contextuallyappropriate understanding of the various inequalities between ethnic or cultural groups that cause conflict.

Psychological perspective emphasizes particular psychological reasons why young people are more prone to engaging in violence. It notes that adolescents may be more susceptible to recruitment by rebel groups or to engage in violence for a number of psychological reasons such as mood swing, emotional immaturity, and appetite to engage in the unknown etc. Job creation schemes are often rationalized as providing restless youth with a means of channeling their energies and thereby resisting a natural propensity to violence in its various forms. This perspective has tended to overstate the threat posed by youth and neglect the positive peace building roles played by youth (Sommers, 2006).

Social and political exclusion: This perspective sees youth violence as a product of the social and political marginalization of young people. A situation where only older individuals are allowed to participate in politics, decision making and have access to economic and political resources can lead to violence as result of social dissatisfaction by youth. When youth are excluded from decision making they tend to see the ruling elites as a mere clique of selfish individuals that need to be changed. And in their attempt to change the situation, if peaceful means proves unfruitful, they may turn to violence as a means of last resort. A number of studies of young people in different conflict-affected countries have identified various social, economic and political barriers that block young peoples' transition to adulthood, and highlighted the central role these barriers can play in driving violent conflict (Sommers' 2006; Amarasuriya et al 2009 and Yousuf 2003). The four different perspectives are presented in table 1.1 below:

Table 1.2: Perspectives on the causes of conflict and their implication for job creation

\begin{tabular}{|l|l|l|}
\hline Perspective & Main Assumption & Implication for Job Creation \\
\hline Greed/opportunity & $\begin{array}{l}\text { Violence is an outcome of rational } \\
\text { individual choices to maximize } \\
\text { economic, political and social benefits. }\end{array}$ & $\begin{array}{l}\text { Broadly-targeted youth creation programmes in } \\
\text { countries with large youth populations to increase } \\
\text { cost of rebellion and generate a 'peace dividend.' }\end{array}$ \\
\hline Grievance & $\begin{array}{l}\text { Violence is an outcome of inequalities or } \\
\text { differences between different societal } \\
\text { groups (especially horizontal } \\
\text { inequalities). }\end{array}$ & $\begin{array}{l}\text { More targeted job creation schemes, based on } \\
\text { contextually-sensitive understanding. Schemes can } \\
\text { reduce horizontal inequalities and build solidarity } \\
\text { across ethnic or cultural divisions. }\end{array}$ \\
\hline Psychological & $\begin{array}{l}\text { Young people are more prone to violence } \\
\text { Social Exclusion }\end{array}$ & $\begin{array}{l}\text { May lead to programming that sees youth as a threat } \\
\text { and neglects positive roles played by youth. }\end{array}$ \\
\hline $\begin{array}{l}\text { Youth violence is a product of the social } \\
\text { people. }\end{array}$ & $\begin{array}{l}\text { Integrated and comprehensive youth programming } \\
\text { that addresses corruption; patrimonialism that } \\
\text { underpins lack of opportunities for young people. }\end{array}$ \\
\hline
\end{tabular}

Source: Walton, 2010 


\section{Conclusion/Major Findings}

This research work concludes that poverty is caused by factors such as social exclusion and marginalization such as denying youth the chance of participating in economic and political decision making; wide income inequality between the rich and the poor; corruption in high and low places such as the 3.2 trillion naira that was invested in Nigeria's power sector between 1999 and 2012, but resulted in diminishing output; poor investment in education that is evident at all levels; unfavorable government policies such as the recent petroleum subsidy removal and the inability of people to access credit facilities. The research also found out that poverty leads to conflict as a result of resource deprivation, feeling of dissatisfaction and grievances that may arise due to social exclusionbase on tribe, region, religion or absolute penury. It is concluded that poverty increases the propensity of youth to engage in armed conflict. Thirdly, armed conflict can be reduced through carefully planned job creation initiatives that consider other causes of violence such as marginalization and income inequality.

\section{Recommendations}

Base on the findings of this paper, the research work recommends the following:

$\checkmark$ The Nigerian government should establish a Dessert and Environmental Hazards Control Commission (DEHCC) that will focus attention on assisting youth in North Eastern and North Western parts of the country to exploit and utilize the natural resources within their environment to achieve economic prosperity. The commission should focus on encouraging self-employment and sustenance of the environment.

$\checkmark$ Governments should encourage private and public investments in the North Eastern and North Western parts of the country as a tool for job creation in the area.

$\checkmark$ Education at all levels should be given utmost priority in the country's budgets. This is to make Nigeria's teeming youth employable in knowledge-driven labour markets of the world.

$\checkmark$ Poverty alleviation programmes and job creation schemes such as NDE, NAPEP and SURE-P should be made more transparent to prevent officials from siphoning the money in the name of ghost beneficiaries.

$\checkmark$ Enhancing war against graft by strengthening anti-corruption institutions in the country with enough legal, financial and administrative muscles to reduce corruption in the country.

$\checkmark$ Government should reduce the trafficking and use of narcotics and hard-drugs in the country to stall the rapid upsurge of drug abuse currently pervading the nation.

\section{References}

[1]. Walton, O. (2010). Youth, armed violence and job creation programmes. Norwegian Peace Building Center and Governance and Social Development Resource Center, University of Birmingham.

[2]. Obasanjo, O. (2005). Budget speech. Nigerian Muse. http://www.nigerianmuse.com

[3]. Olanrewaju, (2011, November 18). Nigeria: Still wallowing in poverty. ThisDay online Newspapers. Retrieved from: http://www.thisday.com

[4]. National Bureau of Statistics (2010) The Nigerian Poverty profile, 2010 report. Contained in press briefing by the Statistician General of the Federation, at the conference room $5^{\text {th }}$ floor, NBS headquarters, Abuja on Monday, $13^{\text {th }}$ January 2012.

[5]. Amarasuriya, H., C. Gündüz, M.M.(2009). Rethinking the nexus between youth, unemployment and conflict-Perspectives from Sri Lanka, Strengthening the Economic Dimensions of Peacebuilding Case Study Series, International Alert.Retrieved from: http://bit.ly/4uXTux

[6]. Collier, P. and Hoeffler, A., (2004). Greed and Grievance in Civil War, Oxford Economic Papers, 56(4): 563-595. Retrieved from: http://bit.ly/cRJlpu

[7]. Sampson, R. J., Raudenbush, S. W. Earls, F. (1997) Neighborhoods and Violent Crime,Science Journal, Vol.277, 918-24.

[8]. Sommers, (2006).Youth and Conflict: A Brief Review of Available Literature', USAID/EUIP Retrieved from: http://www.crin.org

[9]. Urdal, H.(2007). The Demographics of Political Violence: Youth Bulges, Insecurity and Conflict' in Brainard, L. \&Chollet, D. (eds.) 'Too Poor for Peace?' Global Poverty, Conflict and Security in the 21st Century. Washington, DC: Brookings Institution Press (90-100) Retrieved from: http://bit.ly/9NE0TW

[10]. Yousuf, T., (2003). Youth in the Middle East and North Africa: Demography, Employment, and Conflict in Ruble et. Al. (eds.)Youth Explosion In Developing World Cities: Approaches To Reducing Poverty and Conflict In An Urban Age', Woodrow Wilson Centre.Retrieved from: http://bit.ly/9ogRuE

[11]. The United Nations define youth as "persons between the ages of 15 and 24 years old" but in the context of this research, any person between the ages of 15 and 40 can be considered young.

[12]. AOAV \& NWGAV (12 Dec., 2013) The Violent Road: Nigeria's North East. Adamawa, Bauchi, Borno, Gombe, Taraba, Yobe. http://aoav.org.uk 